
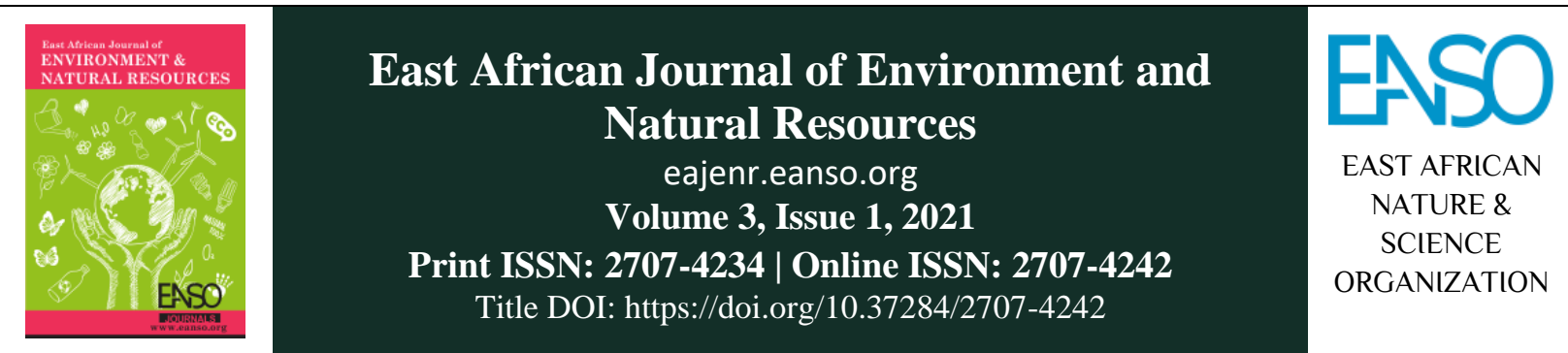

Original Article

\title{
Ecological Responses of Macroinvertebrates to an In-Stream Ecosystem Restoration Technique in a Tropical Stream in Eastern Uganda.
}

\author{
Remigio Turyahabwe ${ }^{1}$, Andrew Mulabbi $i^{*}$, Joyfred Asaba ${ }^{3}$ \& Moses Olowo ${ }^{1}$ \\ ${ }^{1}$ Busitema University, P. O. Box 236, Tororo, Uganda. \\ ${ }^{2}$ Muni University, P. O. Box 725, Arua, Uganda. \\ ${ }^{3}$ Kyambogo university Kampala Uganda P. O. Box 1 Kyambogo, Kampala Uganda. \\ *Correspondence email: mulabbiandrew@yahoo.com.
}

Article DOI: https://doi.org/10.37284/eajenr.3.1.398

\section{Date Published: ABSTRACT}

01 September 2021

A field experiment was conducted to examine the ecological responses of macroinvertebrates to an in-stream ecosystem restoration technique called woody

Keywords: debris introduced in a stream in different arrangements to show how they (woody debris) affected the macroinvertebrate ecology, specifically assemblage

Assemblage, composition and biometrics in River Nabongo. The experiment was carried out in Metrics, two heterogeneous stream environments i.e., i) in a riffle found in the middle Feeding Group, Sampling Plots,

Taxonomic

Composition. reaches of the river at a higher altitude and ii) a pool in the lower altitude and reaches of the river. Each of these two treatments had a control plot for comparison purposes. Four macroinvertebrate sampling campaigns were launched in experimental sites from September 2019 to April 2021. All restoration structures had more macroinvertebrates than control and pre-treatment sites. The introduction of simple structures at the riffle site led to an increase in collector-filterers from 9128 individuals, while at the pool site all the structures increased macroinvertebrates by 1151 individuals. Taxon richness was highest in the complex plot with $14 \pm 0.41$ which significantly differed from the rest of the sampling plots at $\mathrm{P}<0.05$. The relative abundance of taxa at the pool site varied significantly from one sampling plot to another at $\mathrm{P}<0.05$ with the highest mean abundance registered in complex and simple structures having $61.3 \pm 0.10$ and $23.5 \pm 0.11$ respectively. It was concluded that complex woody debris structures increase the diversity, abundance and richness of aquatic macroinvertebrates by providing hard substrates for colonization by algae and microorganisms on which macroinvertebrates feed. We recommended that other researchers should study the impact of other in-stream ecosystem restoration techniques such as floating islands, constructed wetlands, D-

129 | This work is licensed under a Creative Commons Attribution 4.0 International License. 
deflectors, a comparison of which with restored woody debris will enable ecologists to choose the most suitable technique to apply at different stream points.

\begin{abstract}
APA CITATION
Turyahabwe, R., Mulabbi, A., Asaba, J., \& Olowo, M. (2021). Ecological Responses of Macroinvertebrates to an In-Stream Ecosystem Restoration Technique in a Tropical Stream in Eastern Uganda. East African Journal of Environment and Natural Resources, 3(1), 129-144. https://doi.org/10.37284/eajenr .3.1.398
\end{abstract}

\title{
CHICAGO CITATION
}

Turyahabwe, Remigio, Andrew Mulabbi, Joyfred Asaba and Moses Olowo. 2021. "Ecological Responses of Macroinvertebrates to an In-Stream Ecosystem Restoration Technique in a Tropical Stream in Eastern Uganda". East African Journal of Environment and Natural Resources 3 (1), 129-144. https://doi.org/10.37284/eajenr.3.1.398.

\section{HARVARD CITATION}

Turyahabwe, R., Mulabbi, A., Asaba, J., \& Olowo, M. (2021) "Ecological Responses of Macroinvertebrates to an In-Stream Ecosystem Restoration Technique in a Tropical Stream in Eastern Uganda", East African Journal of Environment and Natural Resources, 3(1), pp. 129-144. doi: 10.37284/eajenr.3.1.398.

\section{IEEE CITATION}

R. Turyahabwe., A. Mulabbi., J. Asaba., \& M. Olowo, "Ecological Responses of Macroinvertebrates to an In-Stream Ecosystem Restoration Technique in a Tropical Stream in Eastern Uganda”, EAJENR, vol. 3, no. 1, pp. 129-144, Sep 2021.

\section{MLA CITATION}

Turyahabwe, Remigio, Andrew Mulabbi, Joyfred Asaba \& Moses Olowo. "Ecological Responses of Macroinvertebrates to an In-Stream Ecosystem Restoration Technique in a Tropical Stream in Eastern Uganda". East African Journal of Environment and Natural Resources, Vol. 3, no. 1, Sep 2021, pp. 129-144, doi:10.37284/eajenr.3.1.398.

\section{INTRODUCTION}

The success of ecosystem restoration is desired to increase stability and diversity of species as well as recovery of biotic features. This makes it important to assess and monitor ecosystem restoration practices and processes since ecosystems follow a cyclic pattern. For that reason, therefore, ecologists ought to monitor pre- and post-restoration activities to ensure ecological sustainability and stability of streams Leal et al., (2012). Ecological stream restoration is the return of a stream ecosystem's structure and function to a state that is more reflective of its pre-disturbance form. Regardless of the method applied, the goal of ecological stream restoration is to restore the stream ecosystem's physical, chemical, and biological composition as close as possible to the native state given the permanent watershed alterations (Roni et al., 2002)

Researchers have come up with a wide range of restoration techniques to improve on lotic ecosystems including but not limited to; dam removal to restore longitudinal connectivity, levee breaching to restore lateral connectivity, vegetative methods to control stream bank erosion, riparian road improvements, and physical in-stream restoration (Roni et al., 2002; Shields et al., 2003).
In this study, we concentrated on an in-stream restoration technique that focuses on creating immediately usable habitat i.e., adding woody debris in a tropical stream.

Despite the fact that ecologists in different parts of the world for many centuries agitated for the removal of woody debris from rivers to avoid channel clogging, there has been an increasing knowledge about the ecological importance of woody debris in the rivers (Brooks et al., 2004). This is why European settlers in Australia had concentrated on removing woody debris from rivers but after realizing their ecological importance as habitat enhancement for macroinvertebrates and fish, they embarked on re-introduction of woody debris back to the Australian rivers with the hope that these could optimize pools and riffles which in turn would enhance fish and macroinvertebrate diversity (Gerhard et al., 2000). In this regard, Brooks et al., (2004) carried out an experiment to test the effectiveness of re-introducing woody debris as a means of improving channel stability and recreating habitat diversity for macroinvertebrates. Findings indicated that woody debris was a pivotal 
component of the physical habitat for macroinvertebrates in rivers.

Benke et al. (2003) had earlier observed that reintroducing woody debris in rivers was becoming an important management and restoration strategy in the contemporary world aimed at improving both refuge and biodiversity of macroinvertebrates in rivers. Benke et al., (1985) explained this by indicating that woody debris provides hard substrates for colonisation by algae and microorganisms on which macroinvertebrates feed.

Bilby et al. (1998) defined woody debris as wood materials that are as big as $>3 \mathrm{~cm}$ diameter usually found in forested regions which when subjected to freshwaters slowly decomposes. Bilby et al., (2003) observed that large woody debris that fall in streams form a solid habitat for aquatic organisms and can last for decades. Gurnell et al., (2002) observed that once woody debris fall into running water; they enhance the variability of aquatic ecosystem microhabitats like riffles, runs and pools thereby increasing the diversity, abundance and richness of aquatic organisms like macroinvertebrates.

Submerged woody debris are ecologically important in streams and rivers as they alter streamflow and river bed morphology and profile (Mathooko and Otieno, 2004, Brook et al., 2004). Woody debris submerged in streams enhances macroinvertebrates' habitat which increases the diversity and richness of taxa especially in low flowing rivers (Benke et al., 1984). Woody debris are a widely known food source for specific macroinvertebrate taxa especially Diptera and Caddis fly which do not only use them for food but also secondary production activities specifically pupation and oviposition (Collier et al., 2000) which deems it important to introduce woody debris into rivers.

Hynes et al., (1970) however noted that, knowledge about the importance of woody debris in stream ecology is as young as 70 years old worldwide receiving increased attention in the last 33 years. This is the reason why it has not yet been adopted in most parts of the world like tropical Africa especially East Africa while Uganda in particular totally lacks literature about the same. The available literature on how woody debris have influenced macroinvertebrate structures in streams have concentrated mainly on the temperate world (Lemly \& Hilderbrand, 2000; O'Connor (1991, 1992)). For example, a study by O'Connor (1992) in Australia, revealed that, species richness of macroinvertebrates increased more on individual woody debris that had been introduced than adjacent benthic habitats, while Gurnell et al., (2002) had found out that there was no difference between introduced woody debris and the natural stream habitats.

In east Africa, river channel rehabilitation using riparian vegetation and woody debris would be essential and integral in watershed management strategies (NEMA, 2008) but there is limited research about the same in this region. Apart from Mathooko et al. (2004), hardly are their other researches in East Africa that have examined the impact of woody debris on the restoration of macroinvertebrate structure, yet east African environmental managers need this region-specific information to beef up policies that can guide sustainable freshwater resource conservation. It is against this background therefore that in the current study we carried out an experiment to assess the influence of introduced woody debris structures on macroinvertebrates community assemblages in the tropical river called River Nabongo in Eastern Uganda.

\section{MATERIALS AND METHODS}

\section{Study Area}

River Nabongo drains the eastern slopes of Mount Elgon and is located in Eastern Uganda stretching between $33.5^{0}-36^{0} \mathrm{E}$ and $2^{0}-5^{0} \mathrm{~N}$. It flows into river Muyembe which is part of the larger River Sironko that flows into Lake Kyoga basin. The river flows over a distance of approximately $14 \mathrm{Km}$ with its headwaters originating from the slopes of the northern part of the Mount Elgon range (approximately $1870 \mathrm{~m}$ a.s.l). The biggest part of the relief is mountainous with interceptions of gentle slopes westwards. River Nabongo traverses a natural tropical Forest Reserve in its headwaters in the uppermost reaches and cultivated steep slopes where perennial and annual crops are grown. In the middle reaches, it crosses both perennial and some annual crop farms as well as residential areas while the lower reaches are dominated by annual crop 
farms. River Nabongo crosses a big trading centre at a level of a town board called the NabongoMuyembe town board. The river catchment comprises a variety of climatologically and ecologically different regions, ranging from a yearround wet climate in the source area of the steep Elgon mountains (2000-3000 mm annual rainfall), over a wet climate with two short dry seasons per year (1400 $\mathrm{mm}$ annual rainfall) in the mid-range regions of the system, to the drier downstream region (1000 $\mathrm{mm}$ annual rainfall) with pronounced dry and wet seasons. The mean temperature from the source to the confluence areas varies from below $19^{\circ} \mathrm{C}$ to over $24^{\circ} \mathrm{C}$. (Turyahabwe et al., 2020). The coordinates for the two sampling stations were; $644978.70 \mathrm{mE}, 147820.11 \mathrm{mN}$ (1303M.A.S.L) for the riffle site while the pool site was $644391.39 \mathrm{mE}$, $147735.40 \mathrm{mN}$ (1080M.A.S.L). The experimental sites were lying within a stretch of $2 \mathrm{~km}$ of the stream.

Supporting site characteristics like Dissolved Oxygen, Temperature, and $\mathrm{pH}$ for each site were determined in 'situ' using a multi-parameter analyser model Consort C3010/C3030 dual channel. We measured the velocity, depth, and width of the wetted channel on each site before and after the introduction of woody debris. Velocity was measured using buoyant dry sticks and a stop clock over a stretch of $5 \mathrm{~m}$. The channel width and depth were measured using a tape measure and wading rod. In this study, the velocity at the pool site ranged between $0.4 \pm 0.1$ to $0.5 \pm 0.1 \mathrm{~m} / \mathrm{s}$ while at the riffle site, it ranged between $0.9 \pm 0.2 \mathrm{~m} / \mathrm{s}$ to $1.3 \pm 0.3 \mathrm{~m} / \mathrm{s}$. The width of the wetted channel at the pool site was between $6.7 \pm 0.1 \mathrm{~m}$ to $7.3 \pm 0.4 \mathrm{~m}$ but was narrower at the riffle site ranging between $5.6 \pm 0.5 \mathrm{~m}$ to $6.1 \pm 0.6 \mathrm{~m}$. The channel wet depth ranged between $79.2 \pm 0.2 \mathrm{~cm}$ to $89.2 \pm 18.2 \mathrm{~cm}$ at the riffle site but was deeper at the pool site ranging between $107.0 \pm 13.4 \mathrm{~cm}$ to $141.0 \pm 0.6 \mathrm{~cm}$. The temperature was coolest at the riffle site with a minimum of $20.7 \pm 0.9^{\circ} \mathrm{C}$ but warmer at the pool with $24.2 \pm 1.1^{\circ} \mathrm{C}$. Dissolved oxygen at the pool site was as low as $7.7 \pm 0.7 \mathrm{ppm}$ but highest at the riffle site up to $10.6 \pm 0.2 \mathrm{ppm}$. $\mathrm{pH}$ at both the riffle and pool site ranged between $6.7 \pm 0.4$ to $8.2 \pm 0.4$

\section{Restoration Structure Make Up}

We sampled woody debris that were naturally occurring in the river to find out the dominant wood type submerged in the river. This was to help us know which wood species we needed to use in our experiment. Although very small and very few in number, grooved eucalyptus species (Eucalyptus saligna $\mathrm{Sm}$ ) dominated the submerged woody debris in river Nabongo. Based on this finding, we cut 200 dry grooved eucalyptus woods of species Eucalyptus saligna $\mathrm{Sm}$ with a diameter ranging between $3-5 \mathrm{~cm}$ and $60 \mathrm{~cm}$ long each with their barks intact. These were kept in the river water near the shoreline for 1 week to condition them as submerged woody debris. On retrieval, they were bundled in 10s using a high tensile stainless-steel wire making them 20 bundles (10 bundles were to be installed in a pool site while the other 10 were to be installed in the riffle site). Each bundle was made in form of an inverted funnel (tee-pee) and all the bundles had gaps between sticks/woods of up to $13 \mathrm{~cm}$ to allow macroinvertebrates to enter inside the constructed structure. This is what we called the complex structure.

We also cut 60 grooved eucalyptus woods with diameters ranging from $6-8 \mathrm{~cm}, 60 \mathrm{~cm}$ long each. These were also kept in the river water for 1 week to condition them as submerged woody debris. On retrieval, we arranged and bundled them in groups of 3 woods each bundle making them 20 bundles (10 bundles were to be installed in a pool site while the other 10 were to be installed in the riffle site). This is what we called simple structure. Each of these 20 bundles was bound together with a high tensile stainless-steel wire with gaps in between woods of approximately $13 \mathrm{~cm}$ to allow fish to enter and colonize. The diameter of woods in each case was measured by use of Vanier calliper while the length was measured by use of a tape measure.

\section{Site Treatment}

At the pool site, a stretch of $20 \mathrm{~m}$ was measured; the stream average width was $6.8 \mathrm{~m}$. The $20 \mathrm{~m}$ stretch was divided into 4 sections, where the first $5 \mathrm{~m}$ upstream were reserved as control treatment (no wood was introduced), the second $5 \mathrm{~m}$ was used to install 5complex structures on the left bank and 5 complex structures on the opposite right bank. A 
gap of five metres below the complex structures was skipped to separate complex structures from simple structures. Below this gap, in the remaining $5 \mathrm{~m}$ we installed 5 simple structures on the left bank and the other 5 simple structures on the opposite right bank facing each other. At the riffle site, a similar arrangement of structures was made, only that the channel wet width was smaller $(5.3 \mathrm{~m})$. Each of the structures was installed in the stream slanting at an angle of $>45^{0}$ to break the water velocity. The distance between one structure in each set and another on the same bank side was $20 \mathrm{~cm}$ while that between structures at opposite sides of the banks varied between $0.9-1.8 \mathrm{~m}$ depending on the morphology of the channel.

Each of the structures both simple and complex were stuck in the river's bed by driving 3 unwashed conditioned sticks through the structures and through the substrate on the river's bed vertically in form of a wedge up to a depth of approximately $1.5 \mathrm{ft}$ to avoid washing of structures away by stream water. This design of structure installation in the riffle site was replicated in the pool site. The natural substrate of the pool site was composed of sand, gravel, some mud and cobles while that of the riffle site was composed of sand, cobbles, silt, pebbles and bedrock. Macroinvertebrates were sampled preand post-structure installation. All the sites were monitored for 30 days (enough time for aquatic organisms to colonize a habitat as indicated by O'Connor (1991)) before retrieval/sampling of the structures took place for each sampling campaign.

\section{Macroinvertebrates Sampling and Sorting}

Sampling macroinvertebrates started from downstream of each treatment at each site where a drift net mesh size $0.3 \mathrm{~mm}, 1 \mathrm{~m}$ diameter (at entrance) was used. A whole wood structure with its contents (macroinvertebrates and its detritus) while still inside the river water was carefully lifted and driven inside the drift net and then retrieved/lifted out of the water ensuring that chances of losing macroinvertebrates were minimized as described by (O'Connor 1992; Phillips and Kilambi 1994).

Upon retrieval from water, macroinvertebrates from all similar structures (either simple or complex) for a site were pooled together to form one sample. This was done by removing all macroinvertebrates attached to the woods of a structure using forceps and or jet washing with river water put in a hand sprayer pump ensuring any macroinvertebrates stuck in any wood crevice were dislodged. The macroinvertebrates obtained were put in a container, added $70 \%$ ethanol; container sealed and labelled waiting for further laboratory processing. While in the laboratory, macroinvertebrates were sorted, identified and grouped into their respective feeding and taxonomic groups up to family level following the identification guides set by Merrit and Cummins (1998), same families weighed (wet weight obtained) using 3-digit Dial-O gram to obtain their biomass.

Taxon diversity and richness of macroinvertebrates were determined at each site using Shannon Weaver's Diversity Index (Shannon and Weaver, 1949) to compare the macroinvertebrate taxon diversity between various habitats associated with different wood treatments as follows:

$$
\mathrm{H}=\sum_{\mathrm{i}=1}^{\mathrm{n}}\left(\frac{\mathrm{n}_{\mathrm{i}}}{\mathrm{N}}[\log 2]\left(\frac{\mathrm{n}_{\mathrm{i}}}{\mathrm{N}}\right)\right)
$$

Equation (1) is the Weaver's Diversity Index

Where, $\mathrm{H}=$ Shannon Wiener index of diversity, $\mathrm{n}_{\mathrm{i}}=$ Total No. of individuals of a taxon; $\mathrm{N}=$ Total No. of individuals of all taxa.

Relative abundance of taxa was calculated from the formula denoted by;

\section{R. $A=\quad$ Number of individuals of one taxon X 100 .}

site

Total number of individuals on a

Taxon density of macroinvertebrates was calculated as a ratio of the number of individuals per unit area sampled (total surface area of the woody debris sampled or 1sq.m for the case of untreated plots).

The surface area of the woody debris was calculated by multiplying the diameter with the length of wood used. We added the surface area of individual sticks/woods used to get the total surface area of the respective wood structures used as described by Benke et al., (1984). 
Macroinvertebrate taxon biomass was obtained by dividing the total weight of each family obtained from a sampling plot by the plot area sampled.

\section{Data Analysis}

To compare the differences in macroinvertebrate assemblage metrics, in different sampling plots, a parametric (ANOVA) approach was used. Before the comparison, a normality test using Shapiro-Wilk was applied to macroinvertebrate assemblage metrics. All the data having passed the normality test, one-way ANOVA was performed to assess the differences between means of dependent variables (assemblage metrics) from the different sampling plots. For those models where it was found to be significant under ANOVA, a post hoc test using
Turkey's Honestly Significant Difference (HSD) test was done all generated from STATA version 14.

\section{RESULTS}

\section{Ecological Response of Macroinvertebrates to the In-Stream Ecosystem Restoration Technique}

Data about the response of macroinvertebrates to the in-stream ecosystem restoration technique called woody debris was categorized into two i.e.; macroinvertebrates taxonomic composition and macroinvertebrates assemblage metrics. Summarized in Table1 are the results of macroinvertebrates taxonomic composition. 
Table 1: Macroinvertebrates Taxonomic composition harvested from woody debris structures at river Nabongo experimental sites.

\begin{tabular}{|c|c|c|c|c|c|c|c|c|c|c|}
\hline \multirow[t]{3}{*}{ Order } & \multirow[t]{3}{*}{ Family } & \multirow[t]{3}{*}{ Trophic group } & \multicolumn{4}{|c|}{ POOL SITE } & \multicolumn{4}{|c|}{ RIFFLE SITE } \\
\hline & & & $\begin{array}{l}\text { Before } \\
\text { structures }\end{array}$ & $\begin{array}{l}\text { After } \\
\text { complex } \\
\text { structure }\end{array}$ & $\begin{array}{l}\text { After } \\
\text { simple } \\
\text { structure }\end{array}$ & $\begin{array}{l}\text { Control } \\
\text { plot }\end{array}$ & $\begin{array}{l}\text { Before } \\
\text { structures }\end{array}$ & $\begin{array}{l}\text { After } \\
\text { complex } \\
\text { structure }\end{array}$ & $\begin{array}{l}\text { After } \\
\text { simple } \\
\text { structure }\end{array}$ & $\begin{array}{l}\text { Control } \\
\text { plot }\end{array}$ \\
\hline & & & Total No. & Total No. & Total No. & Total No. & Total No. & Total No. & Total No. & $\begin{array}{l}\text { Total } \\
\text { No. }\end{array}$ \\
\hline Pelecypoda & Corbiculidae & collector-filterer & 7 & 21 & 9 & 4 & & & & \\
\hline Diptera & Simuliidae & collector filterer & & 21 & 9 & & & 12 & & \\
\hline Trichoptera & Hydropsychidae & collector-filterer & 62 & 113 & 55 & 31 & & 17 & 77 & \\
\hline Ephemeroptera & Oligoneuriidae & collector-filterer & 23 & 103 & 29 & 12 & 9 & & 51 & 5 \\
\hline \multirow[t]{2}{*}{ Odonata } & Coenagrionidae & collector-filterer & & 23 & 8 & & & & & \\
\hline & Sub Total & & 92 & 281 & 110 & 47 & 9 & 29 & 128 & 5 \\
\hline Diptera & Chironomidae & collector-gatherer & 18 & 348 & 107 & 9 & & & & \\
\hline Annelida & Leeches & collector-gatherer & & & & & 8 & 11 & 7 & 4 \\
\hline \multirow[t]{2}{*}{ Crustacean } & Palaemonidae & collector -gatherer & & 21 & 33 & & 4 & & 3 & 2 \\
\hline & Sub Total & & 18 & 369 & 140 & 9 & 12 & 11 & 10 & 6 \\
\hline Crustacean & Potamonautidae & Predator & & & & & 1 & & 7 & 1 \\
\hline Trichoptera & Hydrophilidae & Predator & & 58 & 34 & & 18 & 8 & 62 & 9 \\
\hline Ephemeroptera & Perlodidae & Predator & & & & & & 9 & 16 & \\
\hline \multirow[t]{2}{*}{ Odonata } & Libellulidae & Predator & 9 & 25 & 16 & 5 & & 16 & & \\
\hline & Sub Total & & 9 & 83 & 50 & 5 & 19 & 33 & 85 & 10 \\
\hline Pelecypoda & Perlidae & Scrapper & 13 & 19 & 16 & 7 & 9 & 12 & 9 & 5 \\
\hline Trichoptera & Glossosomatidae & Scrapper & & & & & & 9 & 9 & \\
\hline Ephemeroptera & Ephemerellidae & Scrapper & & 91 & 24 & & & 27 & 29 & \\
\hline Ephemeroptera & Heptageniidae & Scrapper & & & & & 17 & 19 & 22 & 9 \\
\hline Hemiptera & Belostomatidae & Scrapper & & & & & 16 & 22 & 8 & 9 \\
\hline \multirow[t]{2}{*}{ Odonata } & Aeshnidae & Scrapper & 11 & 47 & 6 & 6 & & & & \\
\hline & Sub Total & & 24 & 157 & 46 & 13 & 42 & 89 & 77 & 23 \\
\hline Plecoptera & Peltoperlidae & Shredder & & 1 & & & & 2 & & \\
\hline \multirow[t]{2}{*}{ Diptera } & Tipulidae & Shredder & 13 & 54 & 16 & 7 & 11 & 10 & 17 & 6 \\
\hline & Sub Total & & 13 & 55 & 16 & 7 & 11 & 12 & 17 & 6 \\
\hline $\begin{array}{l}\text { Total number of } \\
\text { orders }\end{array}$ & 9 & 5 & 6 & 7 & 8 & 3 & 7 & 8 & 7 & 4 \\
\hline $\begin{array}{l}\text { Total number of } \\
\text { families }\end{array}$ & 20 & & 8 & 14 & 13 & 4 & 8 & 14 & 13 & 4 \\
\hline $\begin{array}{l}\text { Total number of } \\
\text { individuals }\end{array}$ & 2178 & & 156 & 945 & 362 & 81 & 93 & 174 & 317 & 50 \\
\hline
\end{tabular}

135 | This work is licensed under a Creative Commons Attribution 4.0 International License. 
From Table1, it is evident that we harvested a total of 2178 individual macroinvertebrates representing 9 orders, 5 feeding groups and 20 families from experimental sites of the study. The feeding groups were dominated by scrappers with 6 families while shredders were the rarest with only 2 families. The scrappers were algal grazing herbivores feeding on algae that grew on decomposing wood and some that stuck on some stones in current. These scrappers included; Perlidae, Glossosomatidae, Ephemerellidae, Heptageniidae, Belostomatidae and Aeshnidae. Shredders were herbivore chewers and miners of macrophytes on decomposing backs of woody debris. This category can also be called wood excavators. This group was composed of Peltoperlidae and Tipulidae. On the other hand, collector filterers and collector gatherers depended on suspended detritus from and or on entrapped by the wood structures. Collector-filterers were represented by; Oligoneuridae, Hydropsychidae, Simuliidae, Corbiculidae and Coenagrionidae while collector-gatherers were represented by Chironomidae, leeches and Palaemonidae. Predator macroinvertebrate families that existed in the sampling sites included; Potamonautidae, Hydrophilidae, Perlodidae and Libellulidae. These predators depended on preying (biting) on other macroinvertebrates. The 9 orders were dominated by Ephemeroptera, with 4 families while Annelida, Plecoptera and Hemiptera had one family each. Other orders including Crustacea and Pelecypoda were represented by 2 families each. Trichoptera, Odonata and Diptera were each represented by 3 families.

Before the structures were introduced in the pool site, the stream sampling site was dominated by 92 individual collector-filterers which accounted for $59 \%$ of the total site catch with the highest contributor being Hydropsychidae (62 individuals) while the least were predators with 9 individuals of only Libellulidae accounting for $5.7 \%$ of the total site catch. The introduction of complex structures at a pool site came with an increase in the number of collector-filterers from 92 individuals to 281 (threefold increment) of which Hydropsychidae alone were 103 individuals hence the main contributor. Collector-filterers including Simuliidae and Coenagrionidae were only found in the complex structures but were not existing in this pool site pre-treatment. Collector-gatherers increased from 18-369 individuals (20 times) and were the most dominant group in the complex structures at the pool site with Chironomidae family alone contributing 348 individuals. This was the site that had highly polluted detritus entrapped on wood structures on which these high pollution-tolerant non-biting midges fed. The least group were the shredders with only 55 individuals of which 54 belonged to one family called Tipulidae. Since the number of predator macroinvertebrate taxa increased from 9-83, it can be concluded that these predators preyed on shredders more than any other group.

On the other hand, the introduction of simple structures at the pool site attracted fewer macroinvertebrates than complex structures but more than the control plot. Collector-gatherers dominated the simple structures at the pool site with the number of individuals increasing from 18- 140 accounting for $38 \%$ having 140 Chironomidae individuals as the highest contributor. The least group was the shredders with only 16 individuals of Tipulidae accounting for $4.4 \%$ of the total simple structure sample at the pool site. Unlike the simple structures, the control plot had more collector filterers dominating the sample with 47 individuals 31 of which were Hydropsychidae alone and this group accounted for 58\%. The rest of the feeding groups were represented by less than 10 individuals of macroinvertebrates apart from scrappers that had 13 individuals. Generally, the control plot had fewer macroinvertebrates than pre and post-treatments, possibly because the macroinvertebrates found more food and refuge (habitat) in wood structures introduced in the stream.

Before structures were introduced in the riffle site, scrappers were the most dominant feeding group of macroinvertebrates with 42 individuals accounting for $45 \%$, while collector-filterers were the least with only 9 individuals of Oligoneuridae accounting for $9.7 \%$. introduction of complex structures in the riffle site attracted a 2 fold increment of scrappers from $42-89$ as the majority group accounting for $51.1 \%$, while collectorgatherers emerged as the least inhabitant feeding group with only 11 individuals of leeches accounting for $6.3 \%$. The predator group here increased from 19-33. The Ephemerellidae that were not found on the riffle site before the 
East African Journal of Environment and Natural Resources, Volume 3, Issue 1, 2021

Article DOI: https://doi.org/10.37284/eajenr.3.1.398

introduction of structures now started appearing in the system with 27 individuals in complex structures.

Introduction of simple structures at the riffle site came with to increase in collector-filterers from 9128, of which 77 were Hydropsychidae all accounting for $40 \%$ and was the most dominant group. The least abundant group was the collectorgatherers with only 10 individuals, 7 of which were leeches all accounting for $3.2 \%$. Predators increased from $19-85$ accounting for $26.8 \%$. The control plot at the riffle site was dominated by scrappers with 23 individuals while collector-filterers were the least with only 5 individuals of Oligoneuridae. Generally, the control plot had very few taxa and individuals compared to treated/experimental plots.

Based on the difference between the total number of macroinvertebrates harvested before treatment from that after treatment at the riffle site indicates that woody debris that were introduced in the stream led to an increment of macroinvertebrates by 398 individuals while at the pool site the structures increased macroinvertebrates by 1151 individuals. Generally, the complex structures at both riffle and pool sites registered 1119 individuals while simple structures registered 679 individuals, the overall control plots at both sites registered 131 individuals and overall, before treatment yielded249 individuals. This means that complex structures are more effective than simple structures in restoring macroinvertebrate taxa.

\section{Assemblage Metrics of the Macroinvertebrates Harvested from River Nabongo Experimental Restoration Sites}

The means of data about metrics of the macroinvertebrates that were obtained from the experimentation sites for all the four sampling campaigns were summarized in Table 2. A one-way ANOVA was used to explain the distribution of the metrics as summarized in Table 2. 
Table 2: Assemblage metrics of the macroinvertebrates harvested from river Nabongo experimental restoration sites

\begin{tabular}{|c|c|c|c|c|c|c|}
\hline \multirow[t]{2}{*}{ Sampling plots } & Mean Wet weight & $\begin{array}{l}\text { macroinvertebrate } \\
\text { density } \\
\text { (Number/m2) }\end{array}$ & $\begin{array}{l}\text { Macroinvertebrate } \\
\text { taxon } \\
\text { Biomass }(\mathrm{g} / \mathrm{m} 2)\end{array}$ & Diversity & Richness & $\begin{array}{l}\text { Relative } \\
\text { abundance }\end{array}$ \\
\hline & \multicolumn{5}{|l|}{ POOL SITE } & \\
\hline Control plot & $0.45 \pm 0.01^{\mathrm{a}}$ & $6.5 \pm 0.10^{\mathrm{d}}$ & $2.9 \pm 0.08^{\mathrm{b}}$ & $0.8 \pm 0.01^{\mathrm{d}}$ & $8 \pm 0.41^{\mathrm{a}}$ & $5.1 \pm 0.08^{c}$ \\
\hline Before structures & $0.45 \pm 0.02^{\mathrm{b}}$ & $13 \pm 0.41^{\mathrm{c}}$ & $5.8 \pm 0.04^{\mathrm{b}}$ & $1.27 \pm 0.01^{\mathrm{c}}$ & $8 \pm 0.71^{\mathrm{a}}$ & $10.05 \pm 0.43^{\mathrm{d}}$ \\
\hline After simple structure & $0.38 \pm 0.01^{\mathrm{a}}$ & $279 \pm 0.41^{\mathrm{b}}$ & $99 \pm 0.41^{\mathrm{b}}$ & $1.67 \pm 0.01^{\mathrm{b}}$ & $8 \pm 0.4^{\mathrm{a}}$ & $23.5 \pm 0.11^{\mathrm{b}}$ \\
\hline \multirow[t]{2}{*}{ After complex structure } & $0.45 \pm 0.02^{\mathrm{a}}$ & $394 \pm 2.16^{\mathrm{a}}$ & $189 \pm 0.41^{\mathrm{a}}$ & $1.878 \pm 0.01^{\mathrm{a}}$ & $14 \pm 0.41^{\mathrm{b}}$ & $61.3 \pm 0.10^{\mathrm{a}}$ \\
\hline & \multicolumn{5}{|l|}{ RIFFLE SITE } & \\
\hline Control plot & $1.61 \pm 0.01 \mathrm{a}$ & $4 \pm 1.08 \mathrm{c}$ & $7 \pm 0.01 \mathrm{~d}$ & $1.49 \pm 0.03 \mathrm{a}$ & $8 \pm 2.12 \mathrm{a}$ & $7.9 \pm 0.33 \mathrm{~d}$ \\
\hline Before structures & $1.33 \pm 0.24 \mathrm{a}$ & $8 \pm 1.08 \mathrm{~b}$ & $12 \pm 0.41 \mathrm{c}$ & $1.49 \pm 0.01 \mathrm{a}$ & $8 \pm 0.01 \mathrm{a}$ & $14.6 \pm 0.26 \mathrm{c}$ \\
\hline After simple structure & $0.33 \pm 0.01 \mathrm{~b}$ & $2.45 \pm 0.06 \mathrm{c}$ & $82 \pm 1.47 \mathrm{c}$ & $1.62 \pm 0.01 \mathrm{~b}$ & $7 \pm 0.71 \mathrm{a}$ & $50.2 \pm 0.36 \mathrm{a}$ \\
\hline After complex structure & $0.59 \pm 0.01 \mathrm{~b}$ & $73 \pm 1.47 \mathrm{a}$ & $43 \pm 1.78 b$ & $1.58 \pm 0.02 \mathrm{~b}$ & $8 \pm 1.78 \mathrm{a}$ & $27.4 \pm 0.12 b$ \\
\hline it sam & $D, c$ and d) in th & 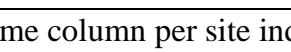 & 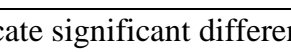 & at $5 \%$ les & & \\
\hline
\end{tabular}

138 | This work is licensed under a Creative Commons Attribution 4.0 International License. 
Based on results in Table 2, apart from the preestablishment of structures, the mean wet weight of macroinvertebrates at the rest of the pool site sampling plots did not vary significantly from plot to plot $(\mathrm{P}>0.05)$. The mean wet weight ranged from $0.38 \pm 0.01 \mathrm{~g}$ in simple structures to $0.45 \pm 0.02 \mathrm{~g}$ in complex structures. Whereas simple structures were associated with reduction in the average wet weight of macroinvertebrates by $0.7 \mathrm{~g}$, complex structures were associated with the same weight as before, so they had no impact on the average wet weight of macroinvertebrates. The highest yield or standing crop/biomass of macroinvertebrates was associated with complex structures with $189 \pm 0.41 \mathrm{~g} / \mathrm{m}^{2}$ which was almost double that from simple structures that yielded $99 \pm 0.41 \mathrm{~g} / \mathrm{m}^{2}$ while the untreated plots yielded the smallest biomasses. The biomass at the complex structures varied significantly from other sampling plots at the pool site at $\mathrm{P}<0.05$. At the riffle site, the mean wet weight in the structures varied significantly from those plots that had no structures at $\mathrm{P}<0.05$. The structures in the riffle site were seen to have been associated with a reduction in the average wet weight and a ground for pupation and hence the ones found were many but at a younger stage so not heavy. The biomass of macroinvertebrates was highest in simple structures with $82 \pm 1.47 \mathrm{~g} / \mathrm{m}^{2}$ but lowest in the control plot with $7 \pm 0.01 \mathrm{~g} / \mathrm{m}^{2}$. Simple structures increased the biomass by $70 \mathrm{~g} / \mathrm{m}^{2}$ while the simple structures increased it by $31 \mathrm{~g} / \mathrm{m}^{2}$. The biomass distribution of pre-treatment was similar to the one of simple structures at $\mathrm{P}>0.05$ but varied significantly from other sampling plots at $\mathrm{P}<0.05$.

The most densely populated sampling plot was complex structures with $394 \pm 2.16$ macroinvertebate individuals $/ \mathrm{m}^{2}$ while the smallest was associated with the control plot with $6.5 \pm 0.10$ macroinvertebrates $/ \mathrm{m}^{2}$. The distribution here varied from one sampling plot to another significantly at $\mathrm{P}<0.05$. The structures that were introduced in the stream increased the density of macroinvertebrates differently, for example, whereas complex structures increased the density by 381 macroinvertebrates $/ \mathrm{m}^{2}$, simple structures increased it by 266macroinvertebrates $/ \mathrm{m}^{2}$. The densest population of macroinvertebrates at the riffle site was associated with complex structures with $73 \pm 1.47$ individuals $/ \mathrm{m}^{2}$. The population was sparse in the simple structures with only $2.45 \pm 0.06$ individuals $/ \mathrm{m}^{2}$. The simple structures reduced macroinvertebrate density by 6 individuals $/ \mathrm{m}^{2}$ while complex structures increased it by 65 individuals $/ \mathrm{m}^{2}$

The taxon diversity was highest in complex structures with $1.878 \pm 0.01$ but lowest in the control plot with $0.8 \pm 0.01$. The distribution of taxon density varied significantly from one sampling plot to another at $\mathrm{P}<0.05$. The diversity of taxa before the introduction of structures into the river was $1.27 \pm 0.01$ meaning that complex structures increased it by 0.6 while, simple structures increased it by 0.2 . Taxon diversity was highest in the simple and complex structures with $1.62 \pm 0.01$ and $1.58 \pm 0.02$ respectively but remained similar and constantly low in the untreated plots at $\mathrm{P}>0.05$ at the riffle site.

Taxon richness remained constant in all sampling plots at the pool site, the complex plot did not only register the highest richness of $14 \pm 0.41$ but also varied significantly from the rest of the sites at $\mathrm{P}<0.05$. on the other hand, on the riffle site, there was no significant variation in the taxon richness at all sampling plots $(\mathrm{P}>0.05)$. The richness ranged between $7 \pm 0.71$ at the simple structures and $8 \pm 2.12$ at the control plot.

The relative abundance of taxa at the pool site varied significantly from one sampling plot to another at $\mathrm{P}<0.05$ with the highest mean abundance in complex and simple structures with $61.3 \pm 0.10 \%$ and $23.5 \pm 0.11 \%$ respectively. Complex restoration structures increased the relative abundance of macroinvertebrates six times while simple structures increased relative abundance by two times unlike the control plot that reduced it by a half, while at the riffle site there was a significant variation in the relative abundance in taxa at all sampling plots $(\mathrm{P}<0.05)$ with the highest at the simple structures with $50.2 \pm 0.36 \%$ while the lowest was $7.9 \pm 0.33 \%$ in the control plot.

\section{DISCUSSION}

\section{Ecological Response of Macroinvertebrates to the In-Stream Ecosystem Restoration Technique}

Generally, the complex structures at both riffle and pool sites registered 1119 individuals while simple 
structures registered 679 individuals, the overall control plots at both sites registered 131 individuals and overall, before treatment yielded249 individuals. This means that complex structures are more effective than simple structures in restoring macroinvertebrate taxa. This is because macroinvertebrates do not only use woody debris for food but also secondary production activities specifically pupation and oviposition. This is similar to what O'Connor (1992) found in Australia when he noted that, macroinvertebrates increased more on individual woody debris that had been introduced than adjacent benthic habitats.

Generally, the control plot had very few taxa and individuals compared to treated/experimental plots with woody debris. This is because untreated plots were severely affected by flow current which led to high juvenile mortality and the current swept a bigger number of juvenile macroinvertebrates that could not resist it hence fewer taxa while wood in the treated plots provided better macroinvertebrate microhabitat diversity that increased their diversity and richness. This was well explained by Gurnell et al., (2002) who observed that once woody debris fall in running water; they enhance the variability of aquatic ecosystem microhabitats like riffles, runs and pools thereby increasing the diversity, abundance and richness of aquatic organisms like macroinvertebrates.

At the pool site, collector-gatherers increased from 18-369 individuals (20 times) and were the most dominant group in the complex structures with Chironomidae family alone contributing 348 individuals. This was an indicator of highly polluted detritus entrapped on wood structures on which these high pollution-tolerant non-biting midges fed. This is similar to an experiment that was carried out by Lehtinen et al. (1997) in River Mississippi in central North America about the importance of woody debris introduction in streams as compared to untreated plots and findings indicated that pollution-tolerant macroinvertebrates species dominated treated (among woody debris) plots more than untreated plots.

\section{Assemblage Metrics of the Macroinvertebrates Harvested from River Nabongo Experimental Restoration Sites}

The highest standing crop/biomass of macroinvertebrates was harvested from complex structures with $189 \pm 0.41 \mathrm{~g} / \mathrm{m}^{2}$ which was almost double that from simple structures that yielded $99 \pm 0.41 \mathrm{~g} / \mathrm{m}^{2}$ while the untreated plots yielded the smallest biomasses. This is because complex structures trapped more and different food types for varied macroinvertebrate taxa meaning that macroinvertebrates did not spend a lot of their energies looking for food, thus increase in their wet weight that could have accounted for their higher biomass as compared to untreated plots at the pool site. This kind of finding is similar to that of Ogren et al. (2008) who noted that the addition of large woody debris in experimental sections increased the total macroinvertebrate biomass by $10 \%$ and Wallace et al., (1999) who indicated that posttreatment biomass found in Cedar Creek was increased by the addition of large woody debris.

Whereas complex structures increased the density by $381 \mathrm{macroinvertebrates} / \mathrm{m}^{2}$, simple structures increased it by 266 macroinvertebrates $/ \mathrm{m}^{2}$ at the pool site. This could be because the complex woody structures were found to fit grounds for pupation and that's why most of the macros found in complex structures were small, light and juvenile. This is similar to Collier et al. 's (2000) notion that Woody debris are a widely known food source for specific macroinvertebrate taxa especially Diptera and Caddis fly which do not only use them for food but also secondary production activities specifically pupation and oviposition

The complex plot registered the highest richness of $14 \pm 0.41$ but remained constant in other sampling plots at the pool site dropping to $7 \pm 0.71$ in simple structures only at the riffle site. This is because woody debris is a means of improving channel stability and recreating habitat diversity for macroinvertebrates hence richness. This is in line with Ogren et al., (2008) who found out that taxa richness increased in treated plots where the number of taxa was $6.7 / \mathrm{m} 2 \pm 1.5$ pre-treatment to $13.0 / \mathrm{m} 2$ \pm 1.7 post-treatment, while Winemiller (2008) also indicated that, taxonomic richness were 
significantly associated with the complexity of woody patches.

Restoration structures increased the relative abundance of macroinvertebrates six times while simple structures increased relative abundance by two times, unlike the control plot that reduced it by half. This is because woody debris provides a hard substrate for colonisation by algae and microorganisms on which macroinvertebrates feed. This finding is in line with Winemiller et al., (2008) who found out that in the Brazos River, the difference between average macroinvertebrate abundance in complex patches versus reference patches was nearly 10 -fold.

The taxon diversity was highest in complex structures with $1.878 \pm 0.01$ but lowest in the control plot with $0.8 \pm 0.01$ compared to before treatment that had1.27 \pm 0.01 . This is because woody debris entraps and retains leaf litter detritus, minerals and organic sediments that are used as food for the different types of macroinvertebrates like collectorgatherers, collector-filterers, scrappers and shredders that were found in complex structures. This finding is in agreement with Ogren et al., 2008) who noted that the Shannon-Wiener diversity index revealed an increase in experimental sections after log placement. Pre-treatment $\mathrm{H}^{\prime}$ values were 1.596 and 1.591 in the control and experimental areas respectively, while post-treatment they increased in the spring (1.629) and (1.874) experimental areas.

\section{CONCLUSION}

Sampling plots that had structures were more densely colonised by macroinvertebrate individuals, trophic groups and taxa than those that did not have structures, an indicator that woody debris restoration are an effective restoration method that should not only be encouraged but should also be adopted by east African ecologists for sustainable river ecosystem Biomonitoring. This is because they were seen to increase macroinvertebrate biomass, density and diversity. Other researchers should study the impact of other in-stream ecosystem restoration techniques such as floating islands, constructed wetlands, D-deflectors a comparison of which with restored woody debris will enable ecologists to choose the most suitable technique to apply at different stream points.

\section{ACKNOWLEDGEMENT}

We are grateful to the biology department of Busitema University for the laboratory space, equipment and expertise you gave us in macroinvertebrate sampling and analysis during the study that made it a successful one.

\section{REFERENCES}

Benke, A. C., Henry III, R. L., Gillespie, D. M., \& Hunter, R. J. (1985). Importance of snag habitat for animal production in southeastern streams. Fisheries, 10(5), 8-13.

Benke, A., \& Wallace, J. B. (2010). Influence of wood on invertebrate communities in streams and rivers. In In: Gregory, $S V$; Boyer, $K L$; Gurnell, AM eds. The ecology and management of wood in world rivers. American Fisheries Society, Symposium 37: Bethesda, Maryland. $p$. 149-177. (Vol. 37, pp. 149-177).

Bilby, R. E. (2003). Decomposition and nutrient dynamics of wood in streams and rivers. In American Fisheries Society Symposium (Vol. 37, pp. 135-147).

Bowen, K. L., Kaushik, N. K., \& Gordon, A. M. (1998). Macroinvertebrate communities and biofilm chlorophyll on woody debris in two Canadian oligotrophic lakes. Archiv für Hydrobiologie, 257-281.

Brooks, A. P., Gehrke, P. C., Jansen, J. D., \& Abbe, T. B. (2004). Experimental reintroduction of woody debris on the Williams River, NSW: geomorphic and ecological responses. River Research and Applications, 20(5), 513-536.

Collier, K. J., \& Halliday, J. N. (2000). Macroinvertebrate-wood associations during decay of plantation pine in New Zealand pumice-bed streams: stable habitat or trophic subsidy? Journal of the North American Benthological Society, 19(1), 94-111.

Francis, T. B., Schindler, D. E., Fox, J. M., \& Seminet-Reneau, E. (2007). Effects of urbanization on the dynamics of organic sediments in temperate lakes. Ecosystems, 10(7), 1057-1068. https://doi.org/10.1007/s10021-0079077-0. 
Gerhard, M., \& Reich, M. (2000). Restoration of streams with large wood: effects of accumulated and built-in wood on channel morphology, habitat diversity and aquatic fauna. International Review of Hydrobiology: A Journal Covering all Aspects of Limnology and Marine Biology, 85(1), 123-137.

Gurnell, A. M., Piégay, H., Swanson, F. J., \& Gregory, S. V. (2002). Large wood and fluvial processes. Freshwater Biology, 47(4), 601-619.

Hynes, H. B. N., \& Hynes, H. B. N. (1970). The ecology of running waters (Vol. 555). Liverpool: Liverpool University Press.

Leal, C. C. (2012). The effects of restored aquatic large woody debris structures on invertebrate populations in the Napa River. San Jose State University. https://doi.org/10.31979/etd.t2mqzhm7

Lehtinen, R. M., Mundahl, N. D., \& Madejczyk, J. C. (1997). Autumn use of woody snags by fishes in backwater and channel border habitats of a large river. Environmental Biology of Fishes, 49(1), 07-19.

Lemly, A. D., \& Hilderbrand, R. H. (2000). Influence of large woody debris on stream insect communities and benthic detritus. Hydrobiologia, 421(1), 179-185.

Mathooko, J. M., \& Otieno, C. O. (2002). Does surface textural complexity of woody debris in lotic ecosystems influence their colonization by aquatic invertebrates?. Hydrobiologia, 489(1), $11-20$.

https://doi.org/10.1023/A:1023214526134.

Merritt, R. W., \& Cummins, K. W. (Eds.). (1996). An introduction to the aquatic insects of North America. Kendall Hunt.

Minello, T. J., \& Zimmerman, R. J. (1983). Fish predation on juvenile brown shrimp, Penaeus aztecus Ives: the effect of simulated Spartina structure on predation rates. Journal of Experimental Marine Biology and Ecology, 72(3), 211-231.

NEMA, (2008), The state of environment report for Uganda, NEMA Kampala, Uganda
NEMA. (2004). The state of environment report for Uganda, NEMA Kampala, Uganda

O'Connor, N. A. (1992). Quantification of submerged wood in a lowland Australian stream system. Freshwater Biology, 27(3), 387-395. https://doi.org/10.1111/j.13652427.1992.tb00548.x

O'Connor, N. A. (1991). The effects of habitat complexity on the macroinvertebrates colonising wood substrates in a lowland stream. Oecologia, 85(4), 504-512.

Ogren, S. A., \& King, D. K. (2008). The effect of large woody debris on macroinvertebrate communities and epilithon detritus composition in a channelized headwater stream. Journal of Freshwater Ecology, 23(1), 65-77. https://doi.org/10.1080/02705060.2008.966455 8.

Phillips, E. C., \& Kilambi, R. V. (1994). Use of coarse woody debris by Diptera in Ozark streams, Arkansas. Journal of the North American Benthological Society, 13(2), 151159.

Roni, P., Beechie, T. J., Bilby, R. E., Leonetti, F. E., Pollock, M. M., \& Pess, G. R. (2002). A review of stream restoration techniques and a hierarchical strategy for prioritizing restoration in Pacific Northwest watersheds. North American Journal of Fisheries Management, 22(1), 1-20.

Schneider, K. N., \& Winemiller, K. O. (2008). Structural complexity of woody debris patches influences fish and macroinvertebrate species richness in a temperate floodplain-river system. Hydrobiologia, $\quad 610(1), \quad 235-244$. https://doi.org/10.1007/s10750-008-9438-5.

Shannon, C.E. \& Weaver, W. (1949) The Mathematical Theory of Communication. University of Illinois Press, Urbana.

Shields, F. D., Knight, S. S., Morin, N., \& Blank, J. (2003). Response of fishes and aquatic habitats to sand-bed stream restoration using large woody debris. Hydrobiologia, 494(1), 251-257. http://dx.doi.org/10.1023/A:1025434920429.

142 | This work is licensed under a Creative Commons Attribution 4.0 International License. 
Turyahabwe, R., Mulinya, C., \& Shivoga, W. A. (2020), Influence of land use/cover on water quality in the River Sironko catchment area, Eastern Uganda. IOSR Journal of Environmental Science, Toxicology and Food Technology (IOSR-JESTFT), 14(8), 26-36.

Wallace, J. B., Eggert, S. L., Meyer, J. L., \& Webster, J. R. (1999). Effects of resource limitation on a detrital-based ecosystem. Ecological monographs, 69(4), 409-442.

Willis, S. C., Winemiller, K. O., \& LopezFernandez, H. (2005). Habitat structural complexity and morphological diversity of fish assemblages in a Neotropical floodplain river. Oecologia, 142(2), 284-295.

143 This work is licensed under a Creative Commons Attribution 4.0 International License. 